\title{
Sprawozdanie
}

\section{Światowy Dzień Wyborów 2012 (GED - Global Election Day), Toruń, 2 lutego 2012 r.}

Dnia 2 lutego 2012 r. na Wydziale Prawa i Administracji Uniwersytetu Mikołaja Kopernika w Toruniu odbyły się ogólnopolskie obchody Światowego Dnia Wyborów 2012 (GED - Global Election Day). Organizatorami przedsięwzięcia były Państwowa Komisja Wyborcza i Krajowe Biuro Wyborcze oraz toruńskie Centrum Studiów Wyborczych UMK i Studenckie Koło Naukowe Prawa Wyborczego „Elektor”.

Obchody „święta demokracji” (jak często określa się wybory) rozpoczęły warsztaty pt. „Młodzi głosują”. Było to spotkanie młodzieży trzecich klas liceów ogólnokształcących z Włocławka, Torunia oraz Chojnic. Zgromadzonych gości przywitał dr Bartłomiej Michalak, politolog współpracujący z toruńskim Centrum. W spotkaniu tym wzięli udział m.in. Zsolt Szlonoki sekretarz Europejskiego Stowarzyszenia Urzędników Wyborczych (ACEEEO), przewodniczący Państwowej Komisji Wyborczej sędzia Stefan Jan Jaworski, szef Krajowego Biura Wyborczego, minister Kazimierz Wojciech Czaplicki, prof. dr hab. Andrzej Sokala - dziekan Wydziału Prawa i Administracji oraz kierownik Centrum Studiów Wyborczych UMK, dr Jarosław Zbieranek - kierownik Programu Prawa i Instytucji Demokratycznych Instytutu Spraw Publicznych w Warszawie.

Podczas spotkania z młodzieżą została przedstawiona prezentacja multimedialna pt. „Informowanie o wyborach w Polsce”. Wystąpienie to dotyczyło problematyki wielkości frekwencji w wyborach, jakie odbyły się w Polsce w latach 2009-2011, form aktywizowania wyborców oraz kampanii profrekwencyjnych. Trzeci temat zwrócił szczególną uwagę zgromadzonej młodzieży, która z entuzjazmem obejrzała przegląd najważniejszych kampanii przygotowanych przez organizacje pozarządowe w latach 2007-2011 („Zmień kraj. Idź na wybory”, „Pępek Europy”, „Gdziekolwiek będziesz, zagłosuj”, „To ważne wybory!”, „Idź na wybory. To jest po prostu bardzo waż- 
ne”, „Przyszłe/li radne/i są tuż obok ciebie! Znasz ich? Przekonaj ich?”, Kobiety na wybory!”, „Głosuj!”).

W ramach akcji zorganizowano spotkanie z ekspertami, podczas którego zaprezentowano wyniki ankiety przeprowadzonej (przez CSW UMK i SKNPW „Elektor”) w styczniu 2012 r. badającej stosunek licealistów do wyborów oraz kampanii profrekwencyjnych organizowanych przed głosowaniem.

Wyniki ankiety prowadzą do następujących wniosków. Młodzi wyborcy korzystają z prawa głosu, ponieważ „chcą decydować” (ogółem 48,89\%). Drugim najczęściej wskazywanym powodem udziału w wyborach jest postrzeganie tej aktywności jako obowiązku (ogółem 28,89\%). W minionych latach preferencje w tym zakresie kształtowały się podobnie. W 2010 r. wyniosły 54,41\% wskazań dla „decydowania” i 20\% dla „obowiązku”, a w 2011 r. odpowiednio $43,55 \%$ i $25,2 \%$ dla obu wariantów. Zdecydowana większość ankietowanych spotkała się z przejawami kampanii profrekwencyjnych w mediach (ogółem 73,02\%, podczas gdy w 2011 r. 71,48\%), ale szczegóły tych kampanii pamięta znikomy procent licealistów (4,76\%, w 2011 r. 7,42\%). Młodzież w większości jako preferowaną formę kampanii profrekwencyjnej wybrała filmy i banery publikowane w Internecie (ogółem 42,53\%). Drugą najczęściej wybieraną formą kampanii były spoty radiowe i telewizyjne (ogółem 21,27\%). Przeważająca część licealistów oceniła swój poziom wiedzy na temat wyborów jako „średni” (dokładnie 60\% wskazań). Odpowiedź „niski” wybrało 17,15\% respondentów.

Podsumowując wyniki ankiety, przewodniczący PKW Stefan Jan Jaworski podkreślił konieczność zachęcania młodych ludzi do korzystania z przysługującego im czynnego prawa wyborczego. Jak zauważył przewodniczący, młodzi ludzie poprzez kartkę wyborczą mają szansę wpłynąć na kształt swojej przyszłości. Z kolei sekretarz PKW minister Kazimierz Wojciech Czaplicki uznał, iż wyniki ankiety wpisują się w nurt profrekwencyjny i zostaną poddane wnikliwej analizie na posiedzeniach Państwowej Komisji Wyborczej.

Kulminacyjnym punktem obchodów Światowego Dnia Wyborów był wykład imienia prof. Wacława Komarnickiego: Instytucjonalne uwarunkowania zachowań wyborczych, który wygłosił prof. dr hab. Jacek Raciborski, socjolog z Uniwersytetu Warszawskiego. W opinii prelegenta działania ludzkie nie są bez reszty determinowane przez normy, normy prawne. Polityka sta- 
nowi wypadkową działań jednostek, a te nie podążają za normami. Normy prawne należy traktować jako przejawy instytucjonalizacji stanów równowagi. Prelegent w interesujący sposób przedstawił proces korzystania przez polskie partie polityczne $\mathrm{z}$ reguł instytucjonalizacji, począwszy od $1989 \mathrm{r}$. Następnie poruszona została problematyka procedur rejestracyjnych, technik głosowania. Dyskutant wyraził opinię de lege ferenda, aby w wyborach do Senatu wprowadzić losowanie jako sposób zapewniania miejsc kandydatom na listach wyborczych. Kolejną kwestią poruszoną przez Jacka Raciborskiego były głosy nieważne. Prelegent zaproponował zbadanie przyczyn tego zjawiska, a nawet stworzenie stosownego raportu. Następnym zagadnieniem omówionym podczas wykładu był termin wyborów. Problem ten bezpośrednio wpływa na zachowanie wyborcze, a zwłaszcza na frekwencję. Także sondaże wyborcze mają tę siłę oddziaływania. W opinii prelegenta, w systemach przewidujących progi wyborcze to właśnie sondaże mogą uruchamiać zachowania strategiczne, polegające na tym, że wyborca nie głosuje na partie o niskim poparciu społecznym, bo nie upatruje on szansę na ich wygraną w wyborach. Sondaże przełamują społeczną atomizację, odgrywają istotną rolę w kształtowaniu opinii publicznej, a więc „trzeba nauczyć się z nimi żyć”. W swoim wystąpieniu Jacek Raciborski zaproponował, aby wiarygodność sondaży poddać kontroli Państwowej Komisji Wyborczej jako stałemu, najwyższemu organowi administracji wyborczej, cieszącemu się zaufaniem obywateli.

Po wygłoszeniu wykładu rozwinęła się dyskusja, w której głos kolejno zabrali m.in.: prof. dr hab. Arkadiusz Żukowski (UWM), przewodniczący PKW Stefan J. Jaworski, minister Kazimierz W. Czaplicki, prof. dr hab. Tadeusz Wasilewski (UMK).

Jacek Raciborski raz jeszcze zwrócił uwagę na żywiołowość procesów wpływających na zachowania wyborcze i podkreślił, iż normy nie determinują do końca zachowań wyborczych. Przewodniczący PKW zwrócił uwagę na zagadnienie sposobu informowania przez media o bieżących sprawach wyborczych, np. o procedurach rejestracji komitetów wyborczych. Natomiast w opinii Kazimierza W. Czaplickiego instytucja zaświadczeń o zarejestrowaniu komitetów w co najmniej połowie okręgów w wyborach powinna być zastąpiona przez obowiązek zebrania 5000 podpisów poparcia. Minister, odnosząc się do problemu głosów nieważnych, wyjaśnił, że w 70\% przyczyną tego zjawiska było wrzucanie do urn wyborczych pustych kart do głoso- 
wania. Kodeks wyborczy nie przewiduje rozliczania głosów nieważnych, po zakończeniu głosowania karty wyborcze oddaje się do depozytu. Nadto minister przypomniał, iż w 1991 r. PKW opracowała dwa projekty ordynacji wyborczej do Sejmu (w systemie większościowym i proporcjonalnym), jeden $\mathrm{z}$ nich przewidywał kaucję wyborczą, jednak pomysłowi jej wprowadzenia zarzucono na etapie prac parlamentarnych, iż stanowi cenzus majątkowy i jest niekonstytucyjny. Minister skonstatował, iż „nie widzi innego rozwiązania, jak istnienie list poparcia kandydatów”.

W opinii Jacka Raciborskiego „polityka skandalu” uniemożliwia przedostanie się do społeczeństwa opinii specjalistów, organów administracji wyborczej. Demokracja liberalna powoduje, iż ludzie są politycznie mniej zaangażowani. Tymczasem Polacy mają większą świadomość prawną niż np. Amerykanie. Najbardziej niekompetentni obywatele na wybory nie chodzą, więc co należy zrobić, aby demokracja przybrała formy partycypacyjne? $\mathrm{Na}$ tak postawione pytanie Jacek Raciborski skonstatował, że: „wolność jest nad obowiązkiem uczestnictwa. Większość z nas będzie szczęśliwa, interesując się sprawami państwa raz po raz. Każde prawo reprodukuje stosunki panowania".

Ogólnopolskie obchody Światowego Dnia Wyborów w Toruniu stały się okazją do kolejnego spotkania przedstawicieli świata nauki prawa wyborczego, socjologii i politologii, a także praktyki wyborczej, stanowiąc ważne forum wymiany wiedzy i doświadczeń.

Radosław Zych

(Centrum Studiów Wyborczych UMK w Toruniu) 